\section{Fertigation Temperature Adjustment Enhances the Yield and Quality of Saffron Grown in a Soilless Culture System}

Yasmina Chourak, El Hassan Belarbi, Evelynn Y. Martínez-Rivera Tatiana Pagan Loeiro da Cunha-Chiamolera, and

Ana Araceli Peña-Fernández

University of Almería, CIAMBITAL [Research Centre for Intensive Mediterranean Agrosystems and Agrifood Biotechnology], Almería, 04120, Spain

\section{José Luis Guil-Guerrero \\ University of Almería, CIAMBITAL [Research Centre for Intensive Mediterranean Agrosystems and Agrifood Biotechnology], Food Technology Division, Department of Agronomy, Almería, 04120, Spain

\author{
Miguel Urrestarazu \\ University of Almería, CIAMBITAL [Research Centre for Intensive Mediterranean \\ Agrosystems and Agrifood Biotechnology], Almería, 04120, Spain
}

Additional index words. crocin, Crocus sativus, flowering, flower forcing, ISO 3632, picrocrocin, root temperature, safranal

\begin{abstract}
Saffron is one of the most appreciated, traditional, and expensive spices in the world. The objective of our study was to evaluate the effect of cooling the nutrient solution on the production, and organoleptic and commercial qualities of saffron grown in soilless culture. The nutrient solution was cooled to 4 to $5^{\circ} \mathrm{C}$ whereas the control treatment was the fertigation supplied at ambient temperature. Corms were placed in a controlled cultivation chamber. The number of flowers per corms, and the weight and length of stigmas were measured. The amounts of safranal, crocin, and picrocrocin were analyzed spectrophotometrically according to the International Organization for Standardization [ISO/TS 3632-2 (2011) Normative]. Our results show that cooling of the nutritive solution increased flower production, the commercial phytochemical content, and organoleptic properties.
\end{abstract}

The cultivation of saffron (Crocus sativus L.) is one of the oldest in the world and has occurred in the region of the Orient, near the Mediterranean, since the Late Bronze Age (Zohary and Hopf, 1994). It is one of the most expensive spices used in the food industry (García-Rodríguez et al., 2017; Hosseinzadeh and Nassiri-Asl, 2012). It is also highly appreciated in many cuisines around the world, and saffron has acquired increasing interest given the health effects of its chemical components, especially from safranal, crocin, and picrocrocin (Molina et al., 2005). This species has potential medical applications, particularly those based on its antitumor and antichronic stress properties (Amin et al., 2016; Ghadrdoost et al., 2011; Naeimi et al., 2019).

Received for publication 18 May 2021. Accepted for publication 18 May 2021.

Published online 23 September 2021.

M.U. is the corresponding author. E-mail: mgavilan@ual.es.

This is an open access article distributed under the CC BY-NC-ND license (https://creativecommons. org/licenses/by-nc-nd/4.0/).
The quality of saffron is evaluated according to its bioactive compound content (Hadizadeh et al., 2007). The greater the amount of bioactive compounds, the greater the quality of saffron (Gohari et al., 2013). Since 1980, the International Organization for Standardization provides a standard procedure (ISO/ TS 3632) for saffron quality classification:

The quality of saffron. Such quality is determined through the spectrophotometric quantification of picrocrocin, safranal and crocin by direct measuring of the absorbance of $1 \%$ standard aqueous solution of dried saffron at 257, 330 and $440 \mathrm{~nm}$, respectively (International Organization for Standardization, 2003).

One of the factors that has proved to be important for the production of high-quality saffron is the environmental temperature at which plants are grown in terms of root and shoot growth, and flower formation (Ahrazem et al., 2015; Molina et al., 2005; Wang et al., 2021). In addition, it is well known that a markedly low temperature $\left(\approx 17^{\circ} \mathrm{C}\right)$ is the best for flower emergence or anthesis from the corm (Molina et al., 2005). This knowledge allows growers to program saffron flowering and increase production in soilless cultivation systems under controlled conditions (Gohari et al., 2013; Wang et al., 2021).

Soilless cultivation systems have been developed through chamber temperature control (Molina et al., 2010; Valero et al., 2004). However, warming the air of the entire greenhouse requires more energy than increasing the root temperature by means of circulating hot water or air through buried tubes (Elwell et al., 1985; Wang et al., 2021). Moreover, warming of the nutrient solution is even cheaper and it is always applied daily as fertigation, given that it is a mandatory action to meet the water and nutrient requirements of the crop (Urrestarazu et al., 2008).

Studies of different species have shown that plant growth is greatly influenced by root temperature (Díaz-Pérez et al., 2007; Nxawe et al., 2009; Solfjeld and Johnsen, 2006). For instance, Urrestarazu et al. (2008) reported that heating the nutrient solution in the 12- to $16-{ }^{\circ} \mathrm{C}$ range was useful for increasing melon yield, and Yan et al. (2012) stated that an increase in root temperature improved nutrient uptake in cucumbers. However, little is known about the effects of increasing the nutrient solution temperature on saffron plants.

The main goal of this work was to determine the effects on yield and bioactive compound content of saffron by modifying the fertigation temperature to a develop low-cost method of obtaining high-quality saffron.

\section{Materials and Methods}

Plant growth conditions. The experiment was carried out in controlled growth chambers located at the University of Almería, Almería, Spain, between 2019 and 2020. The corms of C. sativus were obtained from Minaya (Albacete, Spain). This is a traditional saffron-producing area in Spain under the Regulatory Council Foundation of the Protected Designation of Origen La Mancha (DOP, 2021). Before planting, corms were incubated at $25^{\circ} \mathrm{C}$ (Molina et al., 2004a) for 55 d. On 25 Aug. 2019, corms were transplanted into individual $500-\mathrm{mL}$ containers. The substrate used was commercial coconut fiber, which has defined physicochemical characteristics that have been described by Pozo et al. (2014).

Fertigation treatments. Two nutrient solution temperatures were used: control, 10 to $15^{\circ} \mathrm{C}$; and cooled, 4 to $5^{\circ} \mathrm{C}$ (Fig. 1). The plants were fertigated with a nutrient solution in line with the one described by Sonneveld and Straver (1994). The $\mathrm{pH}$ of the nutrient solutions was adjusted to 5.8 with dilute nitric acid. The nutrient solution was cooled using a refrigerator. Refrigerator, growth chamber, and substrate temperatures were controlled using an Onset Hobo Data Logger U23 Pro v2 (Onset Computer Corp., Bourne, MA). The temperatures were $5{ }^{\circ} \mathrm{C}$ inside the refrigerator, $16^{\circ} \mathrm{C}$ in the culture chamber air, 16 to $17^{\circ} \mathrm{C}$ in the substrate when applying the control 


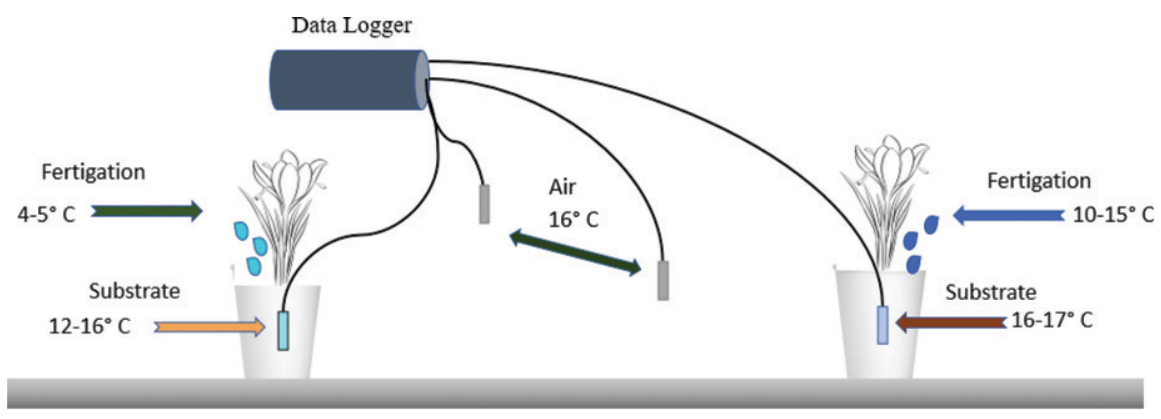

Fig. 1. Schematic experimental unit of saffron crop and point of sample temperature under soilless culture.

nutrient solution, and 15 to $16^{\circ} \mathrm{C}$ in the substrate when the cooled nutrient solution was supplied. The photoperiod was $16 / 8 \mathrm{~h}$ (day/ night) at $16^{\circ} \mathrm{C}$, and the relative humidity was $85 \%$.

Fertigation management was carried out according to the methodology proposed by Urrestarazu et al. (2015). The application of new fertigation was effected when the water in the growing unit reached $10 \%$ of the easily available water (Cunha-Chiamolera et al., 2017; Rodríguez et al., 2014; Urrestarazu et al., 2017). Each treatment was applied four times, and the drainage from all pots for each treatment was collected. The $\mathrm{pH}$, electrical conductivity, and nitrate and potassium content of the nutrient solution and the drainage were measured using a pH-meter (Crison MM40+; Hach LPV2500.98.0002, Bizkaia, Spain), a conductivity meter (EC-Meter Crison BASIC 30, Hach), and a LAQUATwin B-742 and B-731 (Horiba, Northampton, UK), respectively. The volume was measured using a test tube graduated to one-hundredth of a millimeter.

Growth parameters. After flowering, the number of flowers formed per corm was counted, the stigma length was measured before and after the drying process, and the dry and fresh stigma weights were measured with a resolution of $0.1 \mathrm{mg}$.

The vegetative growth of the plants (number of corms formed, and roots and leaves in the dry and fresh states) was measured after $90 \mathrm{~d}$ of flowering. At the end of the experiment, the corms formed per plant were classified according to diameter, and the fresh and dry weights of the leaves were also measured. Roots were rinsed in distilled water to remove substrate residue, weighed, and transferred to paper bags for drying. This was accomplished by placing the material in a convection oven (Heratherm; ThermoScientific, Waltham, MA) at $75^{\circ} \mathrm{C}$ until a constant weight was achieved. This was measured using an OHAUS Adventurer Analytical Precision Analytical Balance (model AX 124/E; OHAUS, Parsippany, NJ), with a precision to four-tenths of a gram (Nájera and Urrestarazu, 2019; Urrestarazu et al., 2016).

Saffron quality analysis. The aqueous extracts of saffron were prepared according to ISO 3632 (International Organization of Standardization, 2011). The saffron filaments were crushed and sieved, and $50 \mathrm{mg}$ of the resulting powder was placed in a $100-\mathrm{mL}$ volumetric flask, to which $90 \mathrm{~mL}$ distilled water was then added. The solution was stirred using a magnetic stir bar at $1000 \mathrm{rpm}$ for $1 \mathrm{~h}$ while being kept away from light. The flask was filled to $100 \mathrm{~mL}$ and the solution was homogenized and filtered. After dilution $(1: 10, \mathrm{v} / \mathrm{v})$, the samples of each treatment were measured in the 200- to 700-nm range using a quartz cell (path length, $1 \mathrm{~cm}$ ). Absorbance readings at 257,310 , and $440 \mathrm{~nm}$ were related back to the $1 \%$ solution and were expressed as E 1\% (257 nm) (maximum absorbance of picrocrocin), E 1\% (330 nm) (maximum absorbance of safranal), and $\mathrm{E}$ $1 \%(440 \mathrm{~nm})$ (maximum absorbance of crocin), according to ISO/TS 3632-2 (International Organization of Standardization, 2003). A blank system was prepared for each. The results were obtained by direct reading of the absorbance $(D)$ as reported in the following equation:

$$
E 1 \%=(D \times 1000) / m(100-M),
$$

where $D$ represents the specific absorbance, $m$ is the weight of the sample, and $M$ is the moisture of the sample.

Moisture was determined by weighing the sample in a watch glass that had been dried and tared previously. The tare containing the test portion was placed in an oven at $103^{\circ} \mathrm{C}$ for $16 \mathrm{~h}$, and was then cooled and weighed using an analytical balance. Moisture $(M)$ was calculated according to the following equation:

$$
M=(m i-m f) \times 100 / m h,
$$

where $m i$ represents the weight of the tare containing the test sample (measured in grams), $m f$ is the weight of the tare more the dry test sample (measured in grams), and $m h$ is the test sample to determine the humidity.

To determine the concentrations of crocin, safranal, and picrocrocin, a standard curve was used according to Khoulati et al. (2019), and the absorbance was recorded using a Helios Gamma UV-Vis Spectrophotometer (Thermo Electron Corporation, Waltham, MA).

Experimental design and statistical analysis. The experiment was performed using a randomized complete block design, with four blocks (Petersen, 1994). The results were subjected to analysis of variance, and the comparison of means was made using Tukey's test $(P \leq 0.05)$ with statistical package Statgraphics Centurion XVII (Statgraphics Technologies Inc., The Plains, VA).

\section{Results and Discussion}

Effect on growth parameters. Flower stigmas are the main commercial product of the saffron plant (Gresta et al., 2008). When the cooled nutrient solution was applied, an improvement of $20 \%$ and $24 \%$ was found in the number of flowers formed and the dry weight of the stigmas, respectively (Table 1). Flower formation mean per corm was $50 \%$ greater than that reported by Molina et al. (2004b) under similar crop conditions. No significant effects were recorded in the remaining vegetative growth parameters. It is well known that air temperature is one of the most important factors to induce saffron flowering (Gresta et al., 2009; Molina et al., 2004a; Wang et al., 2021). Molina et al. (2004a) reported that flower emergence required the transfer of the corms from the conditions of flower formation to a markedly lower air temperature $\left(17^{\circ} \mathrm{C}\right)$. By applying a colder environment, greater flower production was obtained (Gresta et al., 2009). These results were similar to those reported by Urrestarazu et al. (2008) and Yan et al. (2012), who obtained significant benefits in the productivity of horticultural crops under soilless culture by means of modifying the temperature of the nutrient solution and root environment. This is because the root-zone temperature is an important factor in plant growth and water and nutrient uptake (Bode Stoltzfus et al., 1998; Marschner et al., 1996; Mozafar et al., 1993). So, the cooling of the solution is a low-cost and environmentally friendly method of increasing saffron yield.

Effect on chemical components. Under soilless culture, the crocin, safranal, and picrocrocin contents we obtained were significantly greater than those reported by Caballero et al. (2007) (Table 2). After applying cooled fertigation, increases of $16 \%$ and $91 \%$ in safranal and crocin, respectively, were realized. However, no significant differences were found in the amount of picrocrocin. So, the fertigation temperature affects two of the main bioactive compounds of saffron.

Effect on saffron quality. Saffron quality depends on the concentration of its major metabolites according to ISO 3632/2 (International Organization of Standardization, 2011). Table 3 shows significant differences in the quality of saffron characteristics according to nutrient solution temperature as evaluated by absorption values. It is well known that the secondary metabolites (i.e., crocin, picrocrocin, and safranal) range greatly from country to country based on several factors, including climatic conditions, the harvest and drying processes, and storage (Carmona et al., 2005). The data we obtained were within the ranges reported by Carmona et al. (2005). Under cooled fertigation, absorption values for crocin, safranal, and picrocrocin increased by $16 \%, 52 \%$, and $13 \%$, respectively, thus leading to an increase 
Table 1. Yield of saffron grown under soilless culture according to nutrient solution temperature.

\begin{tabular}{lcc}
\hline & \multicolumn{2}{c}{ Nutrient solution temperature } \\
\cline { 2 - 3 } Yield characteristic & 4 to $5^{\circ} \mathrm{C}$ & 10 to $15^{\circ} \mathrm{C}$ \\
\hline No. of flowers/corm & $3.37 \pm 0.45$ & $2.61 \pm 0.19^{* *}$ \\
Stigma (mg/flower) & & \\
$\quad$ Fresh weight & $42.60 \pm 1.99$ & $40.72 \pm 1.89 \mathrm{Ns}$ \\
$\quad$ Dry weight & $8.46 \pm 0.96$ & $7.02 \pm 0.42^{*}$ \\
Length of stigma (cm) & & \\
$\quad$ Fresh & $3.33 \pm 0.07$ & $3.02 \pm 0.42 \mathrm{NS}$ \\
$\quad$ Dry & $2.31 \pm 0.05$ & $2.28 \pm 0.02 \mathrm{NS}$ \\
No. of corms/plant & & \\
$\quad$ Diameter, $>1.5 \mathrm{~cm}$ & $22.00 \pm 2.35$ & $22.00 \pm 3.46 \mathrm{NS}$ \\
$\quad$ Diameter, $<1.5 \mathrm{~cm}$ & $23.80 \pm 3.11$ & $22.00 \pm 2.45 \mathrm{NS}$ \\
Leaves (g/corm) & $81.13 \pm 9.72$ & $78.57 \pm 11.18 \mathrm{NS}$ \\
$\quad$ Fresh weight & $23.80 \pm 0.70$ & $23.72 \pm 2.47 \mathrm{NS}$ \\
$\quad$ Dry weight & & \\
Roots (g/corm) & $12.38 \pm 3.38$ & $16.85 \pm 3.96 \mathrm{Ns}$ \\
$\quad$ Fresh weight & $1.75 \pm 0.39$ & $2.32 \pm 0.40 \mathrm{NS}$ \\
$\quad$ Dry weight & &
\end{tabular}

NS, *, **Nonsignificant or significant at $P \leq 0.05$ or 0.01 , respectively, using Tukey's test $(\mathrm{n}=4)$.

Table 2. Pigment content of saffron according to the nutrient solution temperature (measured in milligrams per gram of stigmas)

\begin{tabular}{lrr}
\hline & \multicolumn{2}{c}{ Nutrient solution temperature } \\
\cline { 2 - 3 } Bioactive compound & \multicolumn{1}{c}{4 to $5^{\circ} \mathrm{C}$} & 10 to $15^{\circ} \mathrm{C}$ \\
\hline Crocin & $117.90 \pm 0.17$ & $101.12 \pm 0.17^{*}$ \\
Safranal & $3.09 \pm 0.01$ & $1.61 \pm 0.31^{* *}$ \\
Picrocrocin & $59.74 \pm 0.01$ & $59.25 \pm 0.01 \mathrm{NS}$ \\
\hline $\mathrm{NS},{ }^{*},{ }^{* *}$ Nonsignificant or significant at $P \leq 0.05$ or 0.01, respectively, using Tukey's test $(\mathrm{n}=4)$.
\end{tabular}

Table 3. Quality characteristics of saffron according to International Organization for Standardization/ TS 3632-2 (2011) Normative versus nutrient solution temperature.

\begin{tabular}{|c|c|c|c|c|c|}
\hline \multirow[b]{2}{*}{ Nutrient solution temperature $^{\mathrm{z}}$} & \multirow[b]{2}{*}{ Value } & \multicolumn{4}{|c|}{ Category } \\
\hline & & I & II & III & IV \\
\hline $\begin{array}{l}\text { E } 1 \%(440 \mathrm{~nm}) \\
\text { absorption value of crocin } \\
4 \text { to } 5^{\circ} \mathrm{C} \\
10 \text { to } 15^{\circ} \mathrm{C}\end{array}$ & $\begin{array}{l}163.80^{*} \\
137.68 \mathrm{NS}\end{array}$ & & $\mathrm{X}$ & $\mathrm{X}$ & \\
\hline $\begin{array}{l}\text { E } 1 \%(330 \mathrm{~nm}) \\
\text { absorption value of safranal } \\
4 \text { to } 5^{\circ} \mathrm{C} \\
10 \text { to } 15^{\circ} \mathrm{C}\end{array}$ & $\begin{array}{l}35.71 * * \\
17.20 \mathrm{NS}\end{array}$ & $\mathrm{X}$ & X & & \\
\hline $\begin{array}{l}\text { E } 1 \%(257 \mathrm{~nm}) \\
\text { absorption value of picrocrocin } \\
4 \text { to } 5^{\circ} \mathrm{C} \\
10 \text { to } 15^{\circ} \mathrm{C}\end{array}$ & $\begin{array}{l}77.64 * \\
67.69 \text { NS }\end{array}$ & $\mathrm{X}$ & $X$ & & \\
\hline
\end{tabular}

${ }^{\mathrm{z}} \mathrm{E} 1 \%(440 \mathrm{~nm})$ is the maximum absorbance of crocin, E $1 \%(330 \mathrm{~nm})$ is the maximum absorbance of safranal, and $\mathrm{E} 1 \%(257 \mathrm{~nm})$ is the maximum absorbance of picrocrocin.

Ns, *, **Nonsignificant or significant at $P \leq 0.05$ or 0.01 , respectively, using Tukey's test $(\mathrm{n}=4)$.

in one level in the commercial ranking for two of the main bioactive compounds of saffron.

The temperature of fertigation is a behavior of a eustressor according to the work by Vázquez-Hernández et al. (2019).

\section{Conclusion}

Fine-tuning the temperature of the nutritive solution increases flower production, and crocin and safranal content without affecting the growth parameters of saffron. Cooling the nutrient solution is an effective, low-cost, and environmentally friendly methodology for
Patents Anticancer Drug Discov. 11(1):121-133, doi: https://doi.org/10.2174/157489281066615110 2110248.

Bode Stoltzfus, R.M., H.G. Taber, and A.S. Aiello. 1998. Effect of increasing root-zone temperature on growth and nutrient uptake by 'Gold Star' muskmelon. J. Plant Nutr. 21(2):321-328, doi: https://doi.org/10.1080/01904169809365406.

Caballero, O.H., M.P. Pereda, and F.I. Abdullaev. 2007. HPLC quantification of major active components from 11 different saffron (Crocus sativus L.) sources. Food Chem. 100(3):1126-1131, doi: https://doi.org/10.1016/j.foodchem.2005.11.020.

Carmona, M., A. Zalacain, J.E. Pardo, E. Lopez, A. Alvarruiz, and G.L. Alonso. 2005. Influence of different drying and aging conditions on saffron constituents. J. Agr. Food Chem. 53(10):3974-3979, doi: https://doi.org/10.1021/jf0404748.

Cunha-Chiamolera, T.P.L., M. Urrestarazu, A.B. Cecílio Filho, and I. Morales. 2017. Agronomic and economic feasibility of tomato and lettuce intercropping in a soilless system as a function of the electrical conductivity of the nutrient solution. HortScience 52(9):1195-1200, doi: https://doi.org/10.21273/hortsci12170-17.

Díaz-Pérez, J.C., R. Gitaitis, and B. Mandal. 2007. Effects of plastic mulches on root zone temperature and on the manifestation of tomato spotted wilt symptoms and yield of tomato. Scientia Hort. 114(2):90-95, doi: https://doi.org/10.1016/ j.scienta.2007.05.013.

DOP. 2021. Azafrán de La Mancha: Denominación de Origen. 21 Jan. 2021. <https:// doazafrandelamancha.com/en/ $>$.

Elwell, D.L., M.Y. Hamdy, W.L. Roller, A.E. Ahmed, H.N. Shapiro, J.J. Parker, and S.E. Johnson. 1985. Soil heating using subsurface pipes: A decade of research results at OSU/ OARDC. Ohio Agr. Res. Dev. Ctr. 1175.

García-Rodríguez, M.V., H. López-Córcoles, G.L. Alonso, C.S. Pappas, M.G. Polissiou, and P.A. Tarantilis. 2017. Comparative evaluation of an ISO 3632 method and an HPLC-DAD method for safranal quantity determination in saffron. Food Chem. 221:838-843, doi: https://doi.org/ 10.1016/j.foodchem.2016.11.089.

Ghadrdoost, B., A.A. Vafaei, A. Rashidy-Pour, R. Hajisoltani, A.R. Bandegi, F. Motamedi, S. Haghighi, H.R. Sameni, and S. Pahlvan. 2011. Protective effects of saffron extract and its active constituent crocin against oxidative stress and spatial learning and memory deficits induced by chronic stress in rats. Eur. J. Pharmacol. 667(1-3):222-229, doi: https://doi.org/ 10.1016/j.ejphar.2011.05.012.

Gohari, A.R., S. Saeidnia, and M.K. Mahmoodabadi. 2013. An overview on saffron, phytochemicals, and medicinal properties. Pharmacogn. Rev. 7(1):61-66, doi: https://doi.org/10.4103/ 0973-7847.112850.

Gresta, F., G. Avola, G.M. Lombardo, L. Siracusa, and G. Ruberto. 2009. Analysis of flowering, stigmas yield and qualitative traits of saffron (Crocus sativus L.) as affected by environmental conditions. Scientia Hort. 119(3):320-324, doi, https://doi.org/10.1016/j.scienta.2008.08.008.

Gresta, F., G.M. Lombardo, L. Siracusa, and G. Ruberto. 2008. Effect of mother corm dimension and sowing time on stigmas yield, daughter corms and qualitative aspects of saffron (Crocus sativus L.) in a Mediterranean environment. J. Sci. Food Agr. 88:1144-1150, doi: https://doi.org/10.1002/jsfa.3177.

Hadizadeh, F., M. Mahdavi, S.A. Emami, Z. Khashayarmanesh, M. Hassanzadeh, J. Asili, A Shariatimoghadam, and R. Noorbakhsh. 2007. Evaluation of ISO method in saffron qualification. 
Acta Hort. 739:405-420, doi: https://doi.org/ 10.17660/actahortic.2007.739.53.

Hosseinzadeh, H. and M. Nassiri-Asl. 2012. Avicenna's (Ibn Sina) the Canon of Medicine and saffron (Crocus sativus): A review. Phytother. Res. 27(4):475-483, doi: https://doi.org/10.1002/ ptr.4784.

International Organization for Standardization (ed.) 2003. TS 3632-1/2: Technical specification: Crocus sativus L. saffron. International Organization for Standardization, Geneva, Switzerland.

International Organization for Standardization. 2011. ISO 3632-1: Saffron (Crocus sativus L.): Specifications. International Organization for Standardization, Geneva, Switzerland.

Khoulati, A., S. Ouahhoud, S. Mamira, K. Alaoui, I. Lahmass, M. Choukri, E.Z. Kharmach, A. Aserhaou, and E. Saalaoui. 2019. Saffron extract stimulates growth, improves the antioxidant components of Solanum lycopersicum L., and has an antifungal effect. Ann. Agr. Sci. 64:138-150, doi: https://doi.org/10.1016/j.aoas.2019.10.002.

Marschner, H., E.A. Kirkby, and I. Cakmak. 1996. Effect of mineral nutritional status on shoot-root partitioning of photoassimilates and cycling of mineral nutrients. J. Expt. Bot. 47:1255-1263, doi: https://doi.org/10.1093/jxb/ 47.Special_Issue.1255.

Molina, R.V., A. García-Luis, V. Coll, C. Ferrer, M. Valero, Y. Navarro, and J.L. Guardiola. 2004a. Flower formation in the saffron crocus (Crocus sativus L): The role of temperature. Acta Hort. 650:39-47, doi: https://doi.org/ 10.17660/actahortic.2004.650.2.

Molina, R.V., B. Renau-Morata, S.G. Nebauer, A. García-Luis, and J.L. Guardiola. 2010. Greenhouse saffron culture: Temperature effects on flower emergence and vegetative growth of the plants. Acta Hort. 850:91-94, doi: https://doi. org/10.17660/actahortic.2010.850.12.

Molina, R.V., M. Valero, Y. Navarro, A. GarciaLuis, and J.L. Guardiola. 2004b. The effect of time of corm lifting and duration of incubation at inductive temperature on flowering in the saffron plant (Crocus sativus L.). Scientia Hort. 103(1):79-91, doi: https://doi.org/10.1016/j. scienta.2004.04.008.

Molina, R.V., M. Valero, Y. Navarro, J.L. Guardiola, and A. García-Luis. 2005. Temperature effects on flower formation in saffron (Crocus sativus L.). Scientia Hort. 103:361-379, doi: https://doi.org/10.1016/j.scienta.2004.06.005.

Mozafar, A., P. Schreiber, and J.J. Oertli. 1993. Photoperiod and root-zone temperature: Interacting effects on growth and mineral nutrients of maize. Plant Soil 153(1):71-78, doi: https:// doi.org/10.1007/bf00010545.

Naeimi, M., M. Shafiee, F. Kermanshahi, Z. Khorasanchi, M. Khazaei, M. Ryzhikov, A. Avan, N. Gorji, and S. Hassanian. 2019. Saffron (Crocus sativus) in the treatment of gastrointestinal cancers: Current findings and potential mechanisms of action. J. Cell. Biochem. 120(10):16330-16339, doi: https://doi.org/10.1002/jcb.29126.

Nájera, C. and M. Urrestarazu. 2019. Effect of the intensity and spectral quality of LED light on yield and nitrate accumulation in vegetables. HortScience 54:1745-1750, doi: https://doi.org/ 10.21273/HORTSCI14263-19.

Nxawe, S., C.P. Laubscher, and P.A. Ndakidemi. 2009. Effect of regulated irrigation water temperature on hydroponics production of spinach (Spinacia oleracea L). Afr. J. Agr. Res. 4(12):1442-1446.

Petersen, G. 1994. Agricultural field experiments: Design and analysis, p. 426. In: Books in soils, plants, and the environment. CRC Press, London, UK.

Pozo, J., J.E. Alvaro, I. Morales, J. Requena, T. La Malfa, P. Mazuela, and M. Urrestarazu. 2014. A new local sustainable inorganic material for soilless culture in Spain: Granulated volcanic rock. HortScience 49:1537-1541, doi: https:// doi.org/10.21273/HORTSCI.49.12.1537.

Rodríguez, D., J. Reca, J. Martínez, M.T. Lao, and M. Urrestarazu. 2014. Effect of controlling the leaching fraction on the fertigation and production of a tomato crop under soilless culture. Scientia Hort. 179:153-157, doi: https://doi. org/10.1016/j.scienta.2014.09.030.

Solfjeld, I. and Ø. Johnsen. 2006. The influence of root-zone temperature on growth of Betula pendula Roth. Trees (Berl.) 20(3):320-328, doi: https://doi.org/10.1007/s00468-005-0043-1.

Sonneveld, C. and N. Straver. 1994. Nutrient solutions for vegetables and flower grow in water substrates. 10th ed. Proefstation voor tuinbouw onder glas te Naaldiwjk, Naaldldwjk, The Netherlands.
Urrestarazu, M., C. Nájera, and M.M. Gea. 2016. Effect of the spectral quality and intensity of light-emitting diodes on several horticultural crops. HortScience 51:268-271, doi: https:// doi.org/10.21273/HORTSCI.51.3.268.

Urrestarazu, M., I. Morales, T. La Malfa, R. Checa, A.F. Wamser, and J.E. Alvaro. 2015. Effects of fertigation duration on the pollution, water consumption, and productivity of soilless vegetable cultures. HortScience 50:819-825, doi: https:// doi.org/10.21273/HORTSCI.50.6.819.

Urrestarazu, M., M.C. Salas, D. Valera, A. Gómez, and P.C. Mazuela. 2008. Effects of heating nutrient solution on water and mineral uptake and early yield of two cucurbits under soilless culture. J. Plant Nutr. 31(3):527-538, doi: https://doi.org/10.1080/01904160801895068.

Urrestarazu, M., V. Gallegos, and J.E. Álvaro. 2017. The Use of thermography images in the description of the humidification bulb in soilless culture. Commun. Soil Sci. Plant Anal. 48(13):1595-1602, doi: https://doi.org/10.1080/ 00103624.2017 .1374399$.

Valero, M., R.V. Molina, Y. Navarro, A. García, and J.L. Guardiola. 2004. El cultivo del azafrán con larga tradición, pero . . ¿ ¿con futuro? Cuadernos de fitopatología. Rev. Tec. Fitop. Entom. 21(80):47-61.

Vázquez-Hernández, M.C., I. Parola-Contreras, L.M. Montoya-Gómez, I. Torres-Pacheco, D. Schwarz, and R.G. Guevara-González. 2019. Eustressors: Chemical and physical stress factors used to enhance vegetables production. Scientia Hort. 250:223-229, doi: https://doi. org/10.1016/j.scienta.2019.02.053.

Wang, Z., X. Li, J. Xu, Z. Yang, and Y. Zhang. 2021. Effects of ambient temperature on flower initiation and flowering in saffron (Crocus sativus L.). Scientia Hort. 279:109859, doi: https:// doi.org/10.1016/j.scienta.2020.109859.

Yan, Q., Z. Duan, J. Mao, X. Li, and F. Dong. 2012. Effects of root-zone temperature and $\mathrm{N}$, $\mathrm{P}$, and $\mathrm{K}$ supplies on nutrient uptake of cucumber (Cucumis sativus L.) seedlings in hydroponics. Soil Sci. Plant Nutr. 58(6):707-717, doi: https://doi.org/10.1080/00380768.2012.733925.

Zohary, D. and M. Hopf. 1994. Domestication of plants in the Old World. 2nd ed. Clarendon Press, Oxford, UK. 